\title{
Physical properties of snacks made from cassava leaf flour
}

\section{Propriedades físicas de snacks de farinha de folhas de mandioca}

\author{
Adriana Cristina Ferrari ${ }^{1}$; Magali Leonel ${ }^{2 *}$; Martha Maria Mischan ${ }^{3}$
}

\begin{abstract}
The food industry is continually growing with new products becoming available every year. Extrusion combines a number of unit operations in one energy efficient rapid continuous process and can be used to produce a wide variety of snacks foods. The objective of this study was to evaluate the effect of extrusion temperature, screw speed, and amount of cassava leaf flour mixed with cassava starch on the physical properties of extruded snacks processed using a single screw extruder. A central composite rotational design, including three factors with 20 treatments, was used in the experimental design. Dependent variables included the expansion index, specific volume, color, water absorption index, and water solubility index. Among the parameters examined, the amount of cassava leaf flour and extrusion temperature showed significant effects on extruded snack characteristics. Mixtures containing $10 \%$ of cassava leaf flour extruded at $100^{\circ} \mathrm{C}$ and $255 \mathrm{rpm}$ shows favorable levels of expansion, color, water absorption index, and water solubility index.
\end{abstract}

Key words: Extrusion, protein, starch, Manihot esculenta Crantz

\section{Resumo}

A indústria de alimentos está crescendo continuamente com novos produtos sendo lançados no mercado a cada ano. A extrusão combina diversas operações unitárias em um processo eficiente, rápido e contínuo e que pode ser usado para produzir uma ampla variedade de snacks. Este trabalho teve como objetivo avaliar o efeito da temperatura de extrusão, rotação de rosca e porcentagem de farinha de folhas de mandioca, misturada com fécula de mandioca, sobre as propriedades físicas dos snacks processados em extrusora monorosca. Foi utilizado o delineamento experimental central composto rotacional para três fatores totalizando 20 tratamentos, considerando como variáveis dependentes o índice de expansão (IE), volume específico (VE), cor ( $\mathrm{L}^{*}, \mathrm{a}^{*}$ e $\mathrm{b}^{*}$ ), o índice de absorção de água (IAA) e o índice de solubilidade em água (ISA). Dentre os parâmetros estudados a porcentagem de farinha de folhas de mandioca e a temperatura de extrusão exerceram efeito mais pronunciado sobre as características avaliadas nos snacks extrusados. Misturas contendo $10 \%$ de farinha de folhas de mandioca extrusadas a $100^{\circ} \mathrm{C}$ e $255 \mathrm{rpm}$ apresentam valores adequados de expansão, cor, índice de absorção de água e índice de solubilidade em água.

Palavras-chave: Extrusão, proteína, amido, Manihot esculenta Crantz

\footnotetext{
${ }^{1}$ Discente do Curso de Zootecnia, Universidade Estadual Paulista "Júlio de Mesquita Filho", Faculdade de Medicina Veterinária e Zootecnia, UNESP, Botucatu, SP, Brasil. E-mail: acferrari89@yahoo.com.br

2 Pesquisadora da UNESP, Centro de Raízes e Amidos Tropicais, UNESP, Botucatu, SP, Brasil. E-mail: mleonel@cerat.unesp.br

${ }^{3}$ Prof $^{\mathrm{a}}$ da UNESP, Instituto de Biociências, Botucatu, SP, Brasil. E-mail: mmischan@ibb.unesp.br

* Author for correspondence
} 


\section{Introduction}

The green leaves of plants have shown to be a good source of protein and are thus an alternative food source for combating malnutrition both indirectly in the form of animal feed and directly in the human diet. In Brazil, cassava leaves have been widely studied because their protein, vitamin, and mineral content are relatively high compared to the levels of these nutrients in other vegetables and grains; moreover, their cost is low and they are abundantly available (MODESTI et al., 2007).

Brazil is the third largest producer of cassava. Cassava is grown in all states of Brazil and is a very important component in food and feed; it is also used as a raw material in various industrial products (LEONEL; FREITAS; MISCHAN, 2009).

A large amount of cassava leaves are wasted during root harvest in all regions of Brazil. It is estimated that for an area of 158 million hectares, more than 178,000 tons of leaves are lost each year. Based on the number of leaves produced per plant per hectare, is possible to obtain approximately $2.250 \mathrm{~kg}$ of cassava leafflour per hectare (SAGRILO et al., 2001).

One option for recovering this waste would be to produce flour, which can be used as a raw material.

Extrusion cooking is a short process carried out under a high temperature, in which food materials are plasticized and cooked through different combinations of temperature, pressure, and mechanical shear, resulting in molecular transformation and chemical reactions.

The thermoplastic extrusion process is used to produce expanded snacks, which are also known as second-generation snacks. These snacks may have optimized characteristics (high fiber content, low calorie content, high protein content, etc.) and can be produced from various raw materials (FERREIRA; CHANG; STEEL, 2011).

Extrusion cooking is preferred over other foodprocessing techniques because it is a continuous, highly productive process that results in significant nutrient retention because of the high temperature and short time required (GUY, 2001). Additionally, the extrusion process denatures undesirable enzymes, inactivates some anti-nutritional factors (for example, trypsin inhibitors, hemagglutinins, tannins, and phytates), sterilizes the finished product, and retains the natural colors and flavors of foods (BHANDARI; D'ARCY; YOUNG, 2001).

Extrudates are microbiologically safe, can be stored for long periods because of their low moisture content, do not require refrigeration, and require less labor for handling, packaging materials, and storage space (FILLI; NKAMA, 2007).

Snacks are normally flavored using fat or oil in the proportion of approximately $20 \%$ as a fixative agent for the flavors, and salt is generally sprinkled on the snack surface. This process results in a snack with a high caloric value and large lipid quantities as well as low protein and fiber content (CAPRILES et al., 2007). Composite foods containing proteins and fiber provide a nutritional psychosocial beneficial quality that enhances acceptance of extruded foods.

Despite the increased use of extrusion processing, extrusion remains a complicated, inefficient process. Small variations in processing conditions affect the process variables as well as the product quality (QING-BO et al., 2005). Thus, we evaluated the effects of various parameters involved in the extrusion process and the amount of cassava leaf flour in a mixture containing cassava starch on developing extruded puffed products.

\section{Materials and Methods}

The raw materials used in this study included industrial cassava starch (Flor de Lotus, Cândido Mota-SP, Brazil) and cassava leaf flour.

To produce cassava leaf flour, cassava leaves harvested at 12 months after cassava planting were washed with water. The leaves were dried in an oven with air circulation at a temperature of $50^{\circ} \mathrm{C}$ 
for $24 \mathrm{~h}$. After drying, the material was ground using knives mill (MA680 - Marconi, Brazil) to obtain the flour.

Proximate analysis (moisture, protein, fat, ash, and crude fiber) was carried out on cassava starch and cassava leaf flour, as per the methods described by the Association of Official Analytical Chemists (AOAC, 1997). The amount of total carbohydrates was calculated by differences.

Cassava starch and cassava leaf flour mixtures were prepared, and moisture content was adjusted to $15 \%$. After homogenization in a "Y" TE201/5 homogenizer (Tecnal, São Paulo, Brazil) for $5 \mathrm{~min}$, 20 samples with $1 \mathrm{~kg}$ were isolated.

Extrusion was carried out using a complete line of Inbra RX50 (Inbramaq, São Paulo, Brazil), which has a motor coupled with a speed reducer (extrusion by mechanical friction), a single extrusion screw, 130-mm barrel diameter, 440-mm extruder length, a hydraulic cooling system for temperature control, variable speed, and a $50 \mathrm{~kg} \mathrm{~h}^{-1}$ capacity.

The extrusion constant parameters were moisture content of mixtures $(15 \%)$, extrusion temperature in the $1^{\text {st }}\left(20-25^{\circ} \mathrm{C}\right)$ and $2^{\text {nd }}$ zones $\left(40-45^{\circ} \mathrm{C}\right)$, screw compression ratio $(3: 1)$, screw diameter $(19 \mathrm{~mm})$, die diameter $(4 \mathrm{~mm})$, feed rate $\left(150 \mathrm{~g} \mathrm{~min}^{-1}\right)$, and cutting speed $(90 \mathrm{rpm})$. The variable parameters in the process were the amount of cassava leaf flour, barrel temperature in the $3^{\text {rd }}$ zone, and screw speed (Table 1). The variation ranges between the upper and the lower limits of variables were established on the basis of preliminary tests.

Table 1. Process variables used in the central composite design for three independent variables.

\begin{tabular}{lccccc}
\hline \multirow{2}{*}{ Independent variables } & \multicolumn{2}{c}{ Levels of variation } & & \\
& $-<$ alpha $>$ & -1 & 0 & +1 & $+<$ alpha $>$ \\
\hline Cassava leaf flour $(\%$ wet basis) & 1.5 & 5.0 & 10.0 & 15.0 & 18.5 \\
Screw speed $(\mathrm{rpm})$ & 238 & 245 & 255 & 265 & 272 \\
Extrusion temperature $\left({ }^{\circ} \mathrm{C}\right)$ & 83 & 90 & 100 & 110 & 117 \\
\hline
\end{tabular}

$<$ alpha $>=1,689$

Source: Elaboration of the authors.

During the extrusion process, a portion of the next test material was used to purge the extruder. The extruded samples were dried $\left(40^{\circ} \mathrm{C}\right)$ to the desired moisture level (6-7\%) in an oven with air circulation (MA037, Marconi, São Paulo, Brazil).

The expansion index, specific volume, color, water absorption index, and water solubility index were examined for the extruded products.

The expansion index (EI) was evaluated after extrusion and before drying by using a digital caliper. Expansion indexes are derived by dividing radial expansion by die orifice diameter $(4.0 \mathrm{~mm})$. The average value was obtained by measuring 20 different expanded products for each treatment (FAUBION; HOSENEY, 1982).
Specific volume (SV) was determined according to the mass displacement method (millet seed) using a graded pipette (FAUBION; HOSENEY, 1982).

The water absorption index (WAI) and water solubility index (WSI) were assessed before and after the extrusion process (ANDERSON; CONWAY; GRIFFIN, 1969). The water absorption index (WAI) is the weight of gel obtained per gram of dry ground sample. Extrudates were ground to a mean particle size of approximately $150 \mu \mathrm{m}$. A 2.5 -g sample was dispersed in $25 \mathrm{~g}$ of distilled water using a glass rod to break up any solids. After stirring for $30 \mathrm{~min}$, the dispersions were rinsed into tared centrifuge tubes, the volume was brought up to $32.5 \mathrm{~g}$, and the tubes were centrifuged at $5000 \mathrm{rpm}$ for $10 \mathrm{~min}$. The water 
solubility index (WSI) is the amount of dry matter recovered after the supernatant is evaporated from the water absorption determination.

Color measurements of ground samples (CIE $\mathrm{L}^{*}, \mathrm{a}^{*}$, and $\mathrm{b}^{*}$ color space) were performed using a Minolta CR-400 model colorimeter(Konica Minolta, Ramsey, NJ, USA). The average value of the three measurements was reported. Color readings were displayed as $L^{*} a^{*} b^{*}$ values where $L^{*}$ represents the lightness/darkness dimension. The positive and negative $a^{*}$ values indicate redness and greenness, respectively, and $b^{*}$ indicates yellowness for a positive value and blueness for a negative value. A white calibration plate was used to standardize the equipment prior to color measurements.

The response surface methodology describes the behavior of a system in which the independent variables $\left(\mathrm{X}_{\mathrm{k}}\right)$ and the dependent variable or responses $\left(\mathrm{Y}_{\mathrm{i}}\right)$ are combined. The response is a function of the levels at which those factors were combined and defined.

Within the proposed variation ranges, i.e., within the region characterized by these levels, the behavior of each response was predicted in a general form according to the following equation:

$\mathrm{Y}_{1}=\beta_{\mathrm{o}}+\beta_{1} \mathrm{X}_{1}+\beta_{2} \mathrm{X}_{2}+\beta_{3} \mathrm{X}_{3}+\beta_{11} \mathrm{X}_{1}^{2}+\beta_{22} \mathrm{X}_{2}^{2}+$ $\beta_{33} X_{3}^{2}+\beta_{12} X_{1} X_{2}+\beta_{13} X_{1} X_{3}+\beta_{23} X_{2} X_{3}+\varepsilon$,

where $Y_{1}=$ Dependent variable or response function; $\mathrm{X}_{1}, \mathrm{X}_{2}, \mathrm{X}_{3}, \mathrm{X}_{4}=$ Values of the independent variables; $\beta_{\mathrm{o}}=$ Coefficient relative to the line interception with the response axis;

$\beta_{1}, \beta_{2}, \beta_{3}=$ Linear coefficients assessed using the least squares method;

$\beta_{11}, \beta_{22}, \beta_{33}=$ Coefficients of quadratic variables;

$\beta_{12}, \beta_{13}, \beta_{23}=$ Coefficients of interaction between independent variables;

$\varepsilon=$ Experimental error

The model was fitted using the option "stepwise" in the SAS program; the obtained model was validated by an F-test using the pure error mean square as the denominator.

Response surfaces plots were drawn from the adjusted models by using the software Statistica ${ }^{\circledR}$ 6.0 .

\section{Results and Discussion}

We characterized the raw materials and found that industrial cassava starch contains few nonstarch components, namely, $0.44 \%$ protein, $0.11 \%$ lipids, $0.39 \%$ total fibers, $0.07 \%$ ash, $0.13 \%$ sugar, $86.06 \%$ starch and $12.8 \%$ water. Leonel, Freitas and Mischan (2009) observed similar results in cassava starch analysis, although protein and fiber content were lower than those observed in our study.

Cassava leaf flour showed high protein $(22.95 \%)$ and total carbohydrate $(21.11 \%)$ contents. These results have also been observed in previous studies, which showed protein contents ranging from 20.77 to $37.94 \%$ (ORTEGA-FLORES et al., 2003; CORRÊA, 2004; WOBETO et al., 2006).

The lipid (13.9\%) and ash (5.96\%) contents observed in cassava leaf flour were similar to those observed in previous studies, in which lipid contents ranged from 3.30 to $16.0 \%$ and ash content ranged from 4.62 to $8.30 \%$ (ORTEGA-FLORES et al., 2003, WOBETO et al., 2006).

The high fiber content (25.78\%) corroborates the variation from 26.50 to $35.40 \%$ reported by Corrêa (2004), and is lower than that reported by OrtegaFlores et al. (2003) who analyzed the nutritional composition of dehydrated cassava leaves $(7.15 \%$ moisture). They found a total fiber content of $48.35 \%$, of which $45.11 \%$ was insoluble fiber and $3.24 \%$ was soluble fiber.

Table 2 summarizes the estimated regression coefficients for the quadratic models fitted to experimental results, their significance, and their corresponding coefficients of determination. 
Table 2. Results of extrusion experiments for coded and independent variables, dependent variables, adjusted models, and determination coefficient.

\begin{tabular}{|c|c|c|c|c|c|c|c|c|c|c|c|c|c|}
\hline & \multicolumn{3}{|c|}{ Coded variables } & \multicolumn{3}{|c|}{$\begin{array}{c}\text { Independent } \\
\text { variables }\end{array}$} & \multicolumn{7}{|c|}{ Dependent variables } \\
\hline & $\mathrm{X} 1$ & $\mathrm{X} 2$ & $\mathrm{X} 3$ & CLF & $\mathrm{T}$ & SS & EI & SV & WAI & WSI & $\mathrm{L}^{*}$ & $\mathrm{a}^{*}$ & $\mathrm{~b}^{*}$ \\
\hline 1 & -1 & -1 & -1 & 5 & 90 & 245 & 3.74 & 5.55 & 5.56 & 53.53 & 55.82 & 0.57 & 20.96 \\
\hline 2 & 1 & -1 & -1 & 15 & 90 & 245 & 3.43 & 5.55 & 6.04 & 59.72 & 53.03 & -0.13 & 20.75 \\
\hline 3 & -1 & 1 & -1 & 5 & 110 & 245 & 2.90 & 7.78 & 5.49 & 56.52 & 59.38 & 1.8 & 19.66 \\
\hline 4 & 1 & 1 & -1 & 15 & 110 & 245 & 2.87 & 5.50 & 4.73 & 58.75 & 58.62 & 0.935 & 19.59 \\
\hline 5 & -1 & -1 & 1 & 5 & 90 & 265 & 3.70 & 6.48 & 5.47 & 52.40 & 55.54 & 0.625 & 21.29 \\
\hline 6 & 1 & -1 & 1 & 15 & 90 & 265 & 3.52 & 7.23 & 7.57 & 60.00 & 49.63 & -0.02 & 20.60 \\
\hline 7 & -1 & 1 & 1 & 5 & 110 & 265 & 3.03 & 9.74 & 6.05 & 46.69 & 61.42 & 1.4 & 20.57 \\
\hline 8 & 1 & 1 & 1 & 15 & 110 & 265 & 2.31 & 7.20 & 4.94 & 55.36 & 55.21 & 1.245 & 19.82 \\
\hline 9 & -1.69 & 0 & 0 & 1,5 & 90 & 255 & 3.89 & 5.12 & 5.29 & 61.70 & 48.09 & 0.65 & 19.91 \\
\hline 10 & 1.69 & 0 & 0 & 18.5 & 90 & 255 & 2.93 & 6.07 & 5.03 & 50.27 & 66.05 & 1.005 & 20.62 \\
\hline 11 & 0 & -1.69 & 0 & 10 & 83 & 255 & 2.81 & 5.21 & 5.37 & 51.93 & 53.05 & 0.455 & 21.02 \\
\hline 12 & 0 & 1.689 & 0 & 10 & 117 & 255 & 2.20 & 10.15 & 6.09 & 47.90 & 60.07 & 2.46 & 18.70 \\
\hline 13 & 0 & 0 & -1.69 & 10 & 100 & 238 & 2.80 & 8.57 & 5.59 & 52.87 & 56.00 & -0.17 & 21.23 \\
\hline 14 & 0 & 0 & 1.689 & 10 & 100 & 272 & 2.47 & 8.45 & 5.48 & 51.42 & 59.46 & 0.83 & 19.74 \\
\hline 15 & 0 & 0 & 0 & 10 & 100 & 255 & 3.41 & 6.20 & 7.30 & 52.57 & 55.17 & -0.48 & 20.72 \\
\hline 16 & 0 & 0 & 0 & 10 & 100 & 255 & 3.42 & 4.45 & 5.92 & 49.21 & 52.60 & -0.32 & 20.87 \\
\hline 17 & 0 & 0 & 0 & 10 & 100 & 255 & 3.27 & 6.02 & 5.75 & 52.63 & 53.07 & -0.27 & 20.64 \\
\hline 18 & 0 & 0 & 0 & 10 & 100 & 255 & 3.53 & 4.69 & 5.09 & 53.19 & 54.04 & -0.43 & 20.75 \\
\hline 19 & 0 & 0 & 0 & 10 & 100 & 255 & 3.48 & 5.34 & 6.16 & 52.69 & 52.80 & -0.24 & 21.07 \\
\hline 20 & 0 & 0 & 0 & 10 & 100 & 255 & 3.43 & 3.13 & 5.16 & 49.13 & 54.56 & -0.4 & 20.63 \\
\hline \multicolumn{9}{|c|}{ Adjusted models } & \multicolumn{2}{|c|}{$\mathrm{R}^{2}$} & \multicolumn{2}{|l|}{$\mathrm{F}_{\text {calc }}$} & $\mathrm{F}_{\mathrm{tab}}$ \\
\hline IE & & \multicolumn{2}{|c|}{0.77} & \multicolumn{2}{|l|}{12.63} & 3.06 \\
\hline VE & \multicolumn{8}{|c|}{$5.08+1.003 \mathrm{x}_{2}+0.84 \mathrm{x}_{5}+1.13 \mathrm{x}_{6}$} & \multicolumn{2}{|c|}{0.65} & \multicolumn{2}{|l|}{10.09} & 3.24 \\
\hline IAA & \multicolumn{8}{|c|}{$5.70-0.56 \mathrm{x}_{7}$} & \multicolumn{2}{|c|}{0.25} & \multicolumn{2}{|l|}{6.09} & 4.41 \\
\hline ISA & \multicolumn{8}{|c|}{$52.02+2.05 \mathrm{x}_{4}$} & \multicolumn{2}{|c|}{0.19} & \multicolumn{2}{|l|}{4.24} & 4.41 \\
\hline $\mathrm{L}^{*}$ & \multicolumn{8}{|c|}{$55.67-3.35 x_{1}^{4}+2.37 x_{2}$} & \multicolumn{2}{|c|}{0.69} & \multicolumn{2}{|l|}{19.2} & 3.59 \\
\hline$a^{*}$ & \multirow{2}{*}{\multicolumn{8}{|c|}{$-0.35-0.22 \mathrm{x}_{1}+0.57 \mathrm{x}_{2}^{2}+0.39 \mathrm{x}_{4}+0.61 \mathrm{x}_{5}+0.21 \mathrm{x}_{6}$}} & \multicolumn{2}{|c|}{0.93} & \multicolumn{2}{|l|}{38.3} & 2.96 \\
\hline $\mathrm{b}^{*}$ & & & & & & & & & \multicolumn{2}{|c|}{0.46} & 15.34 & & 4.41 \\
\hline
\end{tabular}

$\mathrm{X}_{1}=\mathrm{CLF}=$ cassava leaf flour; $\mathrm{X}_{2}=\mathrm{T}=$ temperature $3^{\mathrm{a}}$ zone of extruder; $\mathrm{X}_{3}=\mathrm{SS}=$ screw speed; EI $=$ expansion index; $\mathrm{SV}=$ specific volume; WAI = water absorption index; WSI $=$ water solubility index; $L^{*}=$ luminosity; $a^{*}=a^{*}$ value; $b^{*}=b^{*}$ value; $x_{1}=$ linear effect of cassava leaf flour; $x_{2}=$ linear effect of extrusion temperature; $x_{3}=$ linear effect of screw speed; $x_{4}=$ quadratic effect of cassava leaf flour; $\mathrm{x}_{5}=$ quadratic effect of temperature; $\mathrm{x}_{6}=$ quadratic effect of screw speed; $\mathrm{x}_{7}=$ effect of interaction of cassava leaf flour with temperature; $\mathrm{x}_{8}=$ effect of interaction of cassava leaf flour with screw speed; $\mathrm{x}_{9}=$ effect of interaction of temperature with screw speed; $\mathrm{R}^{2}=$ determination coefficient.

Source: Elaboration of the authors.

Expansion of a food material depends on the pressure difference between the die and the atmosphere. The expansion index of extruded products ranged from 2.20 to 3.89 . Data analysis showed a linear effect of the amount of cassava leaf flour and extrusion temperature and a quadratic effect of temperature and screw speed on this variable.
The expansion ratio indicates the quality of the extruded product and it is associated with crispness, hardness, and chewing. In general, product expansion is directly related to texture, i.e., highly expanded products are crispier.

For extrusion-puffed snacks, one of the most important product characteristic is the degree of 
expansion or puffing. Higher expansion indices are observed under conditions of high extrusion temperature and a lower amount of cassava leaf flour in the mixture, as well as a lower amount of cassava leaf flour and intermediate screw speeds (Figure 1a).

Figure 1. Effect of temperature and percentage of cassava leaf flour on expansion index (a) and temperature and screw speed on specific volume of snacks (b).

(a)
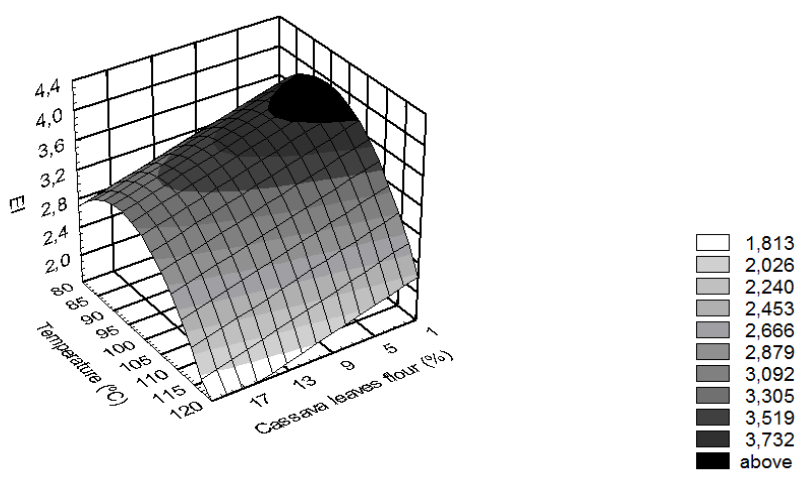

(b)
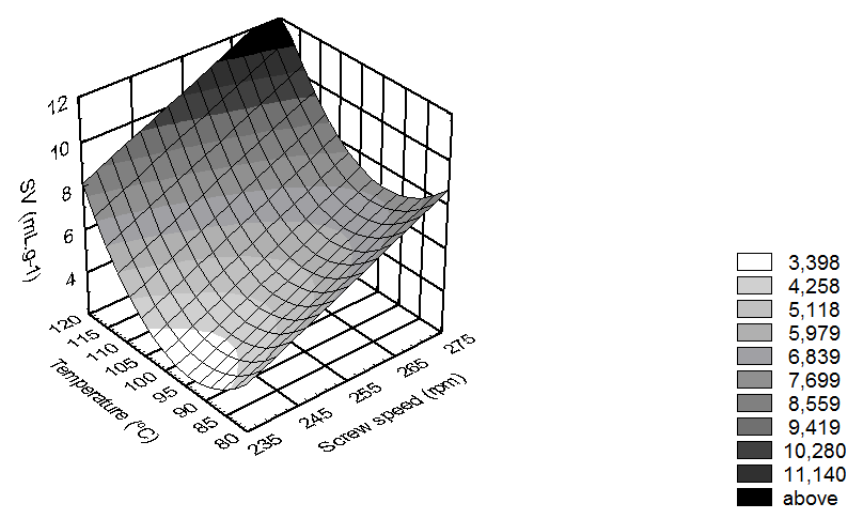

Source: Elaboration of the authors.

During extrusion, the protein and fiber present in cassava leaf flour act as diluents of starch, thereby decreasing the expansion index. The presence of fiber causes fragmentation of cell membranes and prevents gas bubbles from expanding to their maximum capacity, likely due to an increase in the viscous dissipation of the mass, which would increase the friction between the starting material and the surface of the barrel (GUY, 2001).

The puffing phenomena of extrudates result from vaporization of superheated water as the extrudate exits the die. The simultaneous flash-off of vapor expands the starch material, resulting in a porous and sponge like structure within the extrudate. At very high temperatures, vaporization is violent and may cause breakage of the structure, hindering expansion (HASHIMOTO; GROSSMAN, 2003).

Specific volume is a measure of volumetric expansion and a primary parameter associated with measures of brittleness, hardness, water absorption index, and water solubility index of products produced by extrusion cooking. Specific volume is 
directly related to expansion (axial and radial) and negatively correlated with density.

The specific volume of puffed products ranged from 3.13 to $10.15 \mathrm{~mL} \mathrm{~g}^{-1}$. Data analysis showed linear and quadratic effects for the extrusion temperature on the specific volume as well as a quadratic effect for screw speed on this parameter (Table 2). At high temperatures, the specific volume was higher (Figure 1b). When the temperature was increased, the melt viscosity was reduced and axial expansion increased.

The water absorption index (WAI) measures the volume occupied by the extrudate starch after swelling in excess water, which maintains the integrity of starch in aqueous dispersion mixtures (QING-BO et al., 2005).

The water absorption index of extrudates ranged from 4.73 to $7.57 \mathrm{~g}$ gel g$^{-1}$. There were no linear or quadratic effects for the process variable on this parameter, but there was an effect of interaction between the amount of cassava leaf flour and extrusion temperature (Table 2). The model proposed was significant but it was not a predictor model.

The values obtained for the water solubility index (WSI) of the extruded products ranged from 46.69 to $61.70 \%$ (Table 2). The analysis of the regression coefficients showed a quadratic effect of the amount of cassava leaf flour, but the model not can be used as predictor model..

The water solubility index describes the rate and extent to which the component of powder material or particles dissolves in water. It primarily depends on the chemical composition of the powder and its physical state. WSI is often used as an indicator of degradation of molecular components, which measures the degree of starch conversion during extrusion and it is the amount of soluble polysaccharide released from the starch component after extrusion (FILLI et al., 2010).
An increase in the amount of dextrinized starch during extrusion cooking results in an increase in the water solubility index. However, molecular interactions between degraded starch, protein, and other components may reduce solubility (DOGAN; KARWE, 2003).

WAI and WSI are important parameters for defining the applications of extrudates as ingredients and for predicting how the material might behave upon further processing. High WSI is related to the stickiness of the extruded products (SRIBURI; HILL, 2000; HASHIMOTO; GROSSMAN, 2003).

Analysis of the color components of the blends before and after extrusion showed that the values of the $\mathrm{L}^{*}$ component from extruded products varied from 48.09 a 66.01 (Table 2). Data analysis showed a linear effect for the amount of cassava leaf flour and extrusion temperature on the $L^{*}$ value. Higher $L^{*}$ values were obtained under conditions of high extrusion temperature and a low amount of cassava leaf flour (Figure 2a).

The influence of temperature and components of the raw material on the brightness of extruded products has also been reported in other studies. Lustosa, Leonel and Mischan (2010) studied the effects of extrusion parameters on the physical properties of cassava flour and casein mixtures and obtained $L^{*}$ values varying from 59.60 to 77.15 , showing a linear effect of protein in the mixture. Taverna, Leonel and Mischan (2012) analyzed the color components of cassava starch and quinoa flour blends and observed that the values for the $\mathrm{L} *$ component from extruded products varied from 53.05 to 74.69 , with a decrease in luminosity after extrusion. Data analysis revealed the effects of the amount of quinoa flour, screw speed, and extrusion temperature on this parameter. 
Figure 2. Effect of temperature and percentage of cassava leaf flour on luminosity (a) and a* (b) color parameters of extrudates.

(a)
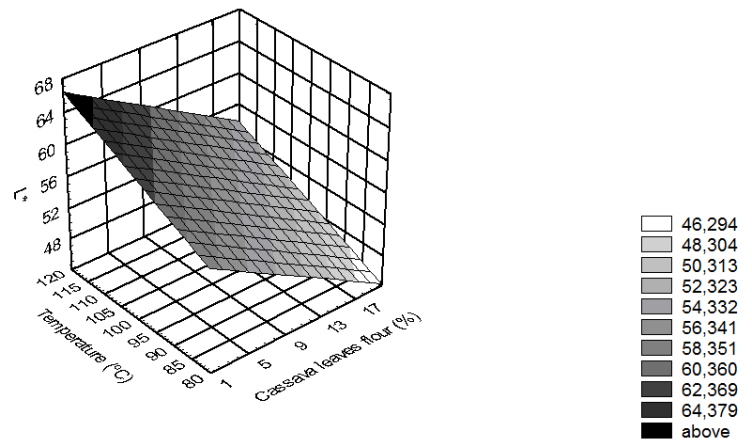

(b)
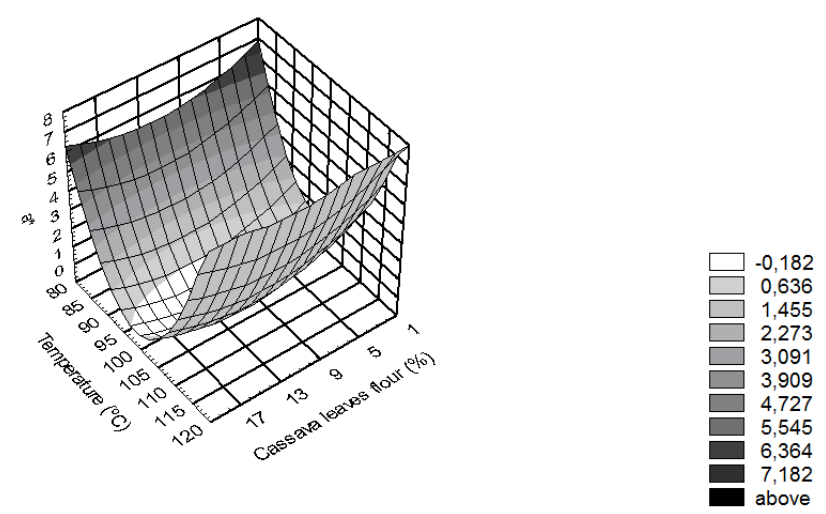

Source: Elaboration of the authors.

The $a^{*}$ value ranged from 2.46 to -0.48 . Data analysis revealed the linear effects of extrusion temperature and the amount of cassava leaf flour on this color parameter. The quadratic effects of temperature, cassava leaf flour, and screw speed were also determined (Table 2).

Under standard testing conditions of screw speed and amount of cassava leaves, we observed lower values for $\mathrm{a}^{*}$. However, under extreme opposite conditions, a higher amount of cassava leaf flour and temperature resulted in higher $\mathrm{a}^{*}$ values (Figure 2b).

Data analysis showed a linear effect for extrusion temperature on the $b^{*}$ value. We observed variation from 18.69 to 21.29 for this color component. The adjusted model not can be considerable predictive.

Color is an important characteristic of extruded foods. Color changes can provide information regarding the extent of browning reactions such as caramelization, Maillard reaction, degree of cooking, and pigment degradation that take place during the extrusion process (ANTON et al., 2008).

\section{Conclusions}

Cassava leaf flour contains levels of protein and fiber and it can be used as a raw material in the extrusion process.

The amount of cassava leaf flour in mixture containing cassava starch affects expansion, water solubility index, water absorption index, and the color of puffed products.

Mixtures containing $10 \%$ cassava leaf flour extruded at $100^{\circ} \mathrm{C}$ and $255 \mathrm{rpm}$ shows favorable 
levels of expansion, color, water absorption index, and water solubility index.

Extrusion is another means by which cassava leaf flour can be utilized.

\section{References}

ANDERSON, R. A.; CONWAY, V. F. P.; GRIFFIN, E. L. Gelatinization of corn grits by roll-and extrusioncooking. Cereal Science Today, Minneapolis, v. 14, n. 4, p. 4-7, 1969.

ANTON, A. A.; ROSS, K. A.; LUKOW, O. M.; FLUCHER, R. G.; ARNTFIELD, S. D. Influence of added bean flour (Phaseolus vulgaris L.) on some physical and nutritional properties of wheat flour tortillas. Food Chemistry, Barking, v. 109, n. 1, p. 33-41, 2008.

ASSOCIATION OF OFFICIAL ANALYTICAL CHEMISTS - AOAC. Official methods of analysis of AOAC International. 16. ed. Gaitheersburg: AOAC, 1997. $850 \mathrm{p}$.

BHANDARI, B.; D'ARCY, B.; YOUNG, G. Flavor retention during high temperature short time extrusion cooking process: a review. International Journal of Food Science and Technology, Oxford, v. 36, n. 5, p. 453-461, 2001.

CAPRILES, V. D.; SOARES, R. A. M.; PINTO E SILVA, M. E. M.; ARÊAS, J. A. G. Effect of fructans-based fat replacer on chemical composition, starch digestibility and sensory acceptability of corn snacks. International Journal of Food Science and Technology, Oxford, v. 44, n. 10, p. 1895-1901, 2007.

CORREAA, A. D. Remoção de polifenóis da farinha de folhas de mandioca. Ciência e Tecnologia de Alimentos, Campinas, v. 24, n. 2, p. 159-164, 2004.

DOGAN, H.; KARWE, M. V. Physicochemical properties of quinoa extrudates. Food Science and Technology International, London, v. 9, n. 2, p. 101-114, 2003.

FAUBION, J. M.; HOSENEY, R. C. High temperature and short time. Extrusion-cooking of wheat starch and flour. I- Effect of moisture and flour type on extrudate properties. Cereal Chemistry, Saint Paul, v. 59, n. 6, p. 529-533, 1982.

FERREIRA, R. E.; CHANG, Y. K.; STEEL, C. J. Influence of wheat bran and of thermoplastic extrusion process parameters on physical properties of cornbased expanded extruded snacks. Alimentos e Nutrição, Araraquara, v. 22, n. 4, p. 507-520, 2011.
FILLI, K. B.; NKAMA, I. Hydration properties of extruded fura from millet and legumes. British Food Journal, Bradford, v. 109, n. 1, p. 68-80, 2007.

FILLI, K. B.; NKAMA, I.; ABUBAKAR, U. M.; JIDEANI, V. A. Influence of extrusion variables on some functional properties of extruded millet-soybeans for the manufacture of 'tura': A Nigerian traditional food. African Journal of Food Science, Lagos, v. 4, n. 6, p. 342-352, 2010.

GUY, R. Raw materials for extrusion cooking. In: Extrusion cooking. Boca Raton: Woodhead Publishing, 2001. p. 5-28.

HASHIMOTO, J. M.; GROSSMANN, M. V. E. Effects of extrusion conditions on quality of cassava bran/ cassava starch extrudates. International Journal of Food Science and Technology, Oxford, v. 38, n. 5, p. 511-517, 2003.

LEONEL, M.; FREITAS, T. S.; MISCHAN, M. M. Physical characteristics of extruded cassava starch. Scientia Agricola, Piracicaba, v. 66, n. 4, p. 486-493, 2009.

LUSTOSA, B. H. B.; LEONEL, M.; MISCHAN, M. M. Parâmetros de extrusão na produção de snacks de farinha de mandioca enriquecidos com caseína. Semina: Ciências Agrárias, Londrina, v. 31, n. 1, p. 129-146, 2010.

MODESTI, C. F.; CORRÊA, A. D.; OLIVEIRA, E. D.; ABREU, C. M. P.; SANTOS, C. D. Caracterização de concentrado protéico de folhas de mandioca obtido por precipitação com calor e ácido. Ciência e Tecnologia Alimentos, Campinas, v. 27, n. 3, p. 464-469, 2007.

ORTEGA-FLORES, C. I.; COSTA, M. A. L.; CEREDA, M. P.; PENTEADO, M. V. C. Avaliação da qualidade protéica da folha desidratada de mandioca (Manihot esculenta Crantz). Nutrire: Revista da Sociedade Brasileira de Alimentação e Nutrição, São Paulo, v. 25, p. 47-59, 2003.

QING-BO, D.; AINSWORTH, P.; TUKER, G.; MARSON, H. The effect of extrusion conditions on the physicochemical properties and sensory characteristics of rice - based expanded snacks. Journal of Food Engineering, Amsterdam, v. 66, n. 3, p. 284-289, 2005.

SAGRILO, E.; VIDIGAL FILHO, O. S.; PEQUENO, M. G.; RIMOLDI, F. Quantificação e caracterização dos resíduos agrícolas de mandioca no estado do Paraná. In: CEREDA, M. P. (Coord.). Agricultura: tuberosas amiláceas latino-americanas. São Paulo: Fundação Cargill, 2001. v. 2, cap. 19, p. 413-434. (Série Culturas de tuberosas latino-americanas). 
SRIBURI, P.; HILL, S. E. Extrusion of cassava starch with either variations in ascorbic acid concentration or pH. International Journal of Food Science and Technology, Oxford, v. 35, n. 2, p. 141-154, 2000.

TAVERNA, L. G.; LEONEL, M.; MISCHAN, M. M. Changes in physical properties of extruded sour cassava starch and quinoa flour blend snacks. Ciência e Tecnologia de Alimentos, Campinas, v. 32, n. 4, p. 826834, 2012.
WOBETO, C.; CORRÊA, A. D.; ABREU, A. C. P.; SANTOS, C. D.; ABREU, J. R. Nutrients in the cassava (Manihot esculenta Crantz) leaf meal at three ages of the plant. Ciência e Tecnologia de Alimentos, Campinas, v. 26, n. 4, p. 865-869, 2006. 